\title{
Tantangan Penggunaan M-Learning Mahasiswa Universitas Sains Al-Qur'an Wonosobo
}

\author{
Dian Asmarajati ${ }^{7}$ \\ dianaj@fastikom-unsiq.ac.id
}

\begin{abstract}
The fact that students have mobile technology does not mean they use it for their academic activities. This research aims to discover what students do with their mobile devices? What guidance did they receive from their lecturers at the university? This research answers are built from a theoretical framework and involves collecting data from samples. For example, problems such as the ability to manage time and learning activities, what students know about technology, what activities they do with it, or what they have learned about it in the context of school education. This study is an analysis of social phenomena. Construction data techniques were chosen so as to enable students to express their own assumptions and analyze their social practices such as semi-open surveys of students, semi-structured interviews with faculty and focus groups with students. All information obtained is then triangulated. It was found that they used their mobile devices even though there were no instructions from their lecturers. Although departing audiovisual has turned into a favorite tool of young people to try to gather information, it turns out students do not make it a choice for learning. Therefore this has become an opportunity to promote the use of mobile technology for academic purposes.
\end{abstract}

Keywords: M-Learning, Mobile Device, Technology, Universitas Sains Al-Qur'an.

\footnotetext{
7 Tehnik Informatika Universitas Sains Al-Qur'an Wonosobo
} 


\section{PENDAHULUAN}

$\mathrm{S}$

emua aspek kehidupan telah tersentuh oleh penggunaan teknologi mobile. Teknologi mobile saat ini telah membuat perubahan sosial di berbagai bidang kehidupan manusia (Cavus, 2011). Dalam konteks pendidikan, perkembangan pesat teknologi mobile juga mendorong penggunaan dalam lingkungan belajar mengajar. Implementasinya yang disebut dengan mobile learning dianggap sebagai tren pembelajaran terkini (Segaran, Ali, \& Hoe, 2014).

Banyak peneliti dan pendidik saat ini sedang menjajaki potensi teknologi mobile untuk mendukung proses pembelajaran di banyak mata pelajaran karena m-learning memberi kesempatan untuk mengubah strategi pembelajaran klasik yang ada untuk memberi siswa banyak cara fleksibel untuk mengelola pengalaman belajar mereka sendiri. Sejalan dengan peluang tersebut, teknologi juga memberikan tantangan. Kompleksitas teknologi mobile dalam memfasilitasi banyak aspek kehidupan sehari-hari masih diasumsikan akan mengganggu fokus pembelajaran. Asumsi ini memberi kita tantangan untuk mengetahui bagaimana menciptakan lingkungan yang dapat mendukung pengaturan dan aktivitas pembelajaran mobile yang berbeda

Banyak metode pembelajaran yang mengadopsi penggunaan teknologi komputer dan internet dalam bentuk e-learning, online learning dan mobile learning. M-learning didefinisikan sebagai metode pembelajaran baru yang dibantu dengan menggunakan perangkat mobile. (Chachila, Engkamat, Sarkawic, \& Shuib, 2015). M-learning merupakan elaborasi pembelajaran e-learning dan online learning khususnya dengan menggunakan perangkat mobile. Belajar dengan perangkat mobile akan memberikan peserta didik lebih banyak fleksibilitas dalam belajar karena memungkinkan peserta didik mendapatkan materi pelajaran kapanpun dan dimanapun karena menggunakan perangkat mobile (Ozdamli \& Cavus, 2011).

Mahasiswa baru di universitas sains alquran wonosobo memiliki teknologi mobile dengan akses Internet, dan mereka menggunakannya dalam kehidupan sehari-hari. Melalui teknologi ini, dapat diduga bahwa mereka mengakses sumber daya yang terkait dengan studi universitas mereka. Oleh karena itu, dapat dianggap bahwa fakta-fakta memiliki perangkat mobile dan memiliki akses Internet yang digabungkan bersama-sama mengarahkan diri mereka pada skenario pembelajaran yang disebut $\mathrm{m}$ learning. Namun demikian, kedua fakta ini hanyalah beberapa kondisi yang memungkinkan pembelajaran itu terjadi. Jadi, keduanya bisa disebut sebagai persyaratan kunci yang diperlukan untuk berlansungnya m-learning untuk tugas mereka mempelajari dan membangun pengetahuan (Spiegel, 2010).

Belajar adalah konstruksi subyektif, di mana siswa harus terlibat penuh. untuk mempelajari potensi untuk menjadi kenyataan, diperlukan adanya faktor-faktor yang harus dipenuhi seperti keterlibatan pribadi siswa; struktur kognitif dan pengetahuan sebelumnya yang memungkinkan informasi baru terintegrasi secara signifikan (Ausubel, 2002); keterampilan yang terkait dengan organisasi waktu dan kondisi material yang diperlukan untuk belajar, tugas atau intervensi pendidikan dan akses teknologi mobile ke informasi di Internet dan ke sumber daya yang disediakan oleh pengajar atau instruktur. Beberapa persyaratan ini tergantung pada masing-masing mahasiswa; misalnya, keterlibatan dalam proses pembelajaran, dan pengetahuan sebelumnya untuk secara bermakna mengintegrasikan dan memahami konsep-konsep baru.

Karenanya, untuk mendeteksi apakah proses belajar terjadi pada mahasiswa, penelitian ini fokus menelusuri aspek keterampilan yang berkaitan dengan pengaturan waktu dan kondisi lain yang diperlukan untuk belajar, yang merupakan atau seharusnya menjadi tanggung jawab dosen atau pengajar. Dalam hal ini, kami menyelidiki beberapa hal pokok seperti tugas apa yang diberikan dosen kepada siswa, kegiatan akademik apa di luar tugas dari dosen yang dilakukan siswa dengan teknologi mobile mereka, keterampilan manajemen waktu dan pelatihan atau bimbingan apa yang telah mereka terima dari dosen atau pengajar mereka. 


\section{METODE PENELITIAN}

Penelitian ini merupakan penelitian Kualitatif dengan pendekatan fenomenologi. Subyek dalam penelitian ini adalah 100 mahasiswa semester satu Universitas Sains Alquran Wonosobo dari berbagai program studi dan 5 dosen yang dipilih secara random. Alat yang dipilih adalah survei semi-terbuka untuk mahasiswa dan dosen, wawancara semi-terstruktur untuk dosen dan diskusi dengan mahasiswa. Datadata ini kemudian triangulasi satu sama lain (Jick, 1979) dan dianalisi menggunakan statistik deskriptif sehingga untuk memahami proses sosial terkait dengan objek penelitian, dan memperkaya analisis (Flick, 1998) dengan kombinasi pendekatan yang berbeda dari pengakuan dari beragam subyek dan perspektif dalam penelitian ini.

\section{HASIL DAN PEMBAHASAN}

Selama bulan September-Oktober 2018, survei tentang penggunaan teknologi mobile yang dilakukan tehadap mahasiswa baru di Universitas Sains alquran wonosobo. Ditemukan bahwa hampir $100 \%$ siswa memiliki perangkat mobile dan sebagian besar dari mereka memiliki akses ke Internet, setidaknya setengah hari atau aktif hanya menggunakan jaringan wifi di kampus, seperti yang dapat dilihat pada gambar 1.

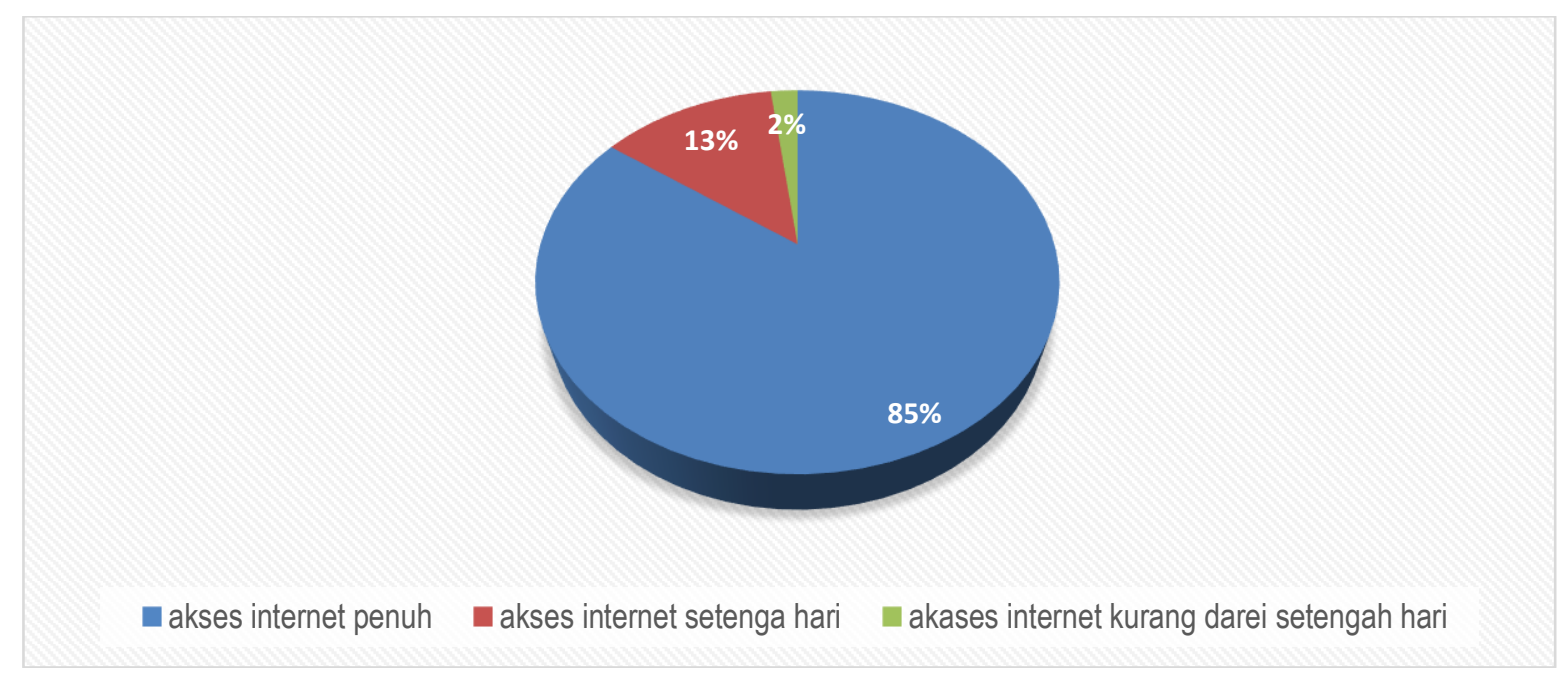

\section{Gambar 1. Presentase Akses Perangkat Mobile}

Sebagian besar siswa mengatakan mereka belajar sendiri tentang pengelolaan perangkat mobile mereka (Spiegel, 2013). Bukan diajarkan oleh orang tua dosen atau atau teman sebaya. Oleh karena itu, mahasiswa diasumsikan tidak belajar tentang penggunaan teknologi mobile baik di sekolah maupun di universitas. Fakta ini bisa dilihat dari hasil survey berikut. 


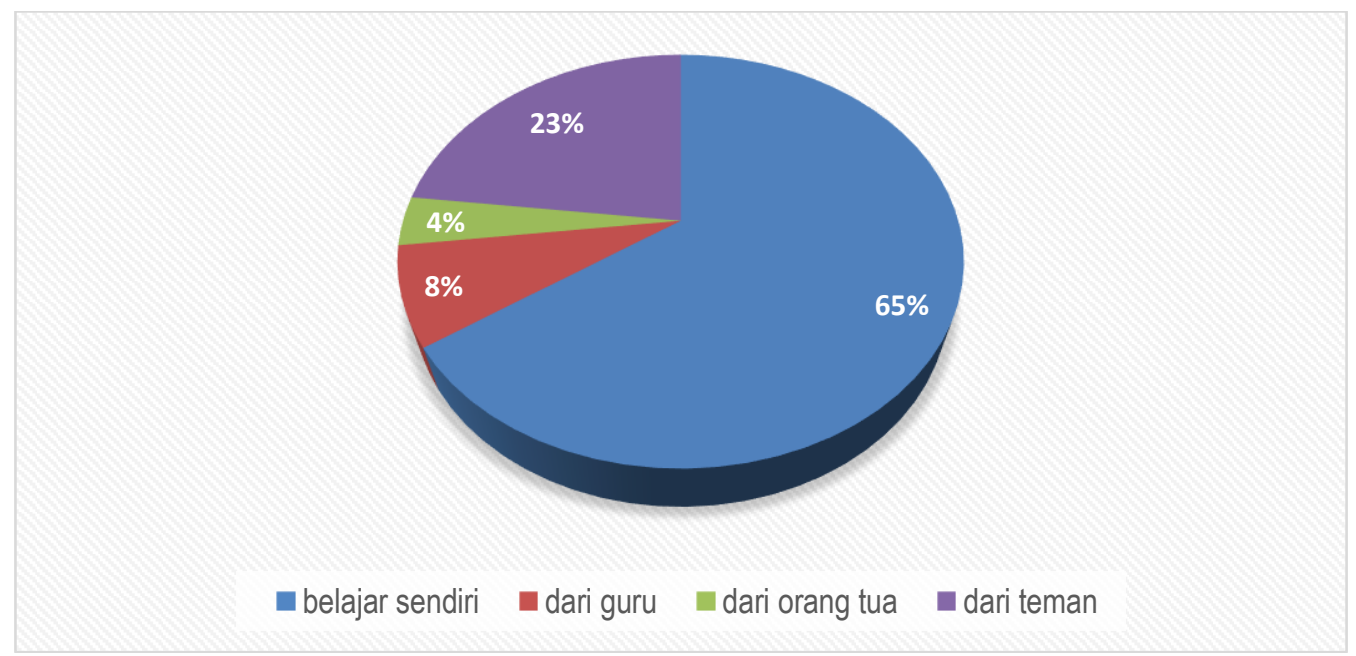

Gambar 2. Presentase Perolehan Pengetahuan tentang Perangkat Mobile

Ketika siswa ditanya tentang penggunaan perangkat seluler untuk tujuan akademik, dengan inisiatif mereka sendiri atau karena diperintahkan oleh dosen, hasilnya yang ditunjukkan pada gambar 3 .

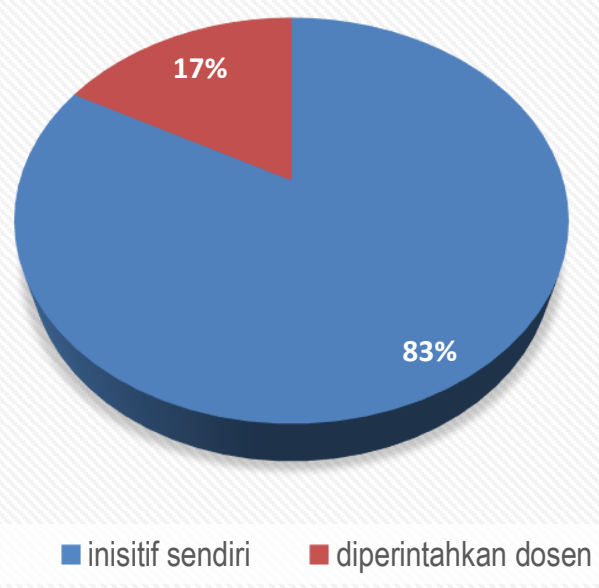

Gambar 3. Presentase Alasan Penggunaan Perangkat Mobile untuk Belajar

Sangat menarik bahwa, $65 \%$ siswa belajar menggunakan perangkat mobile secara mandiri dan menggunakanya untuk keperluan akademik juga atas inisiatif sendiri (83\%). Hanya 17\% yang merespon menyatakan bahwa para dosen mereka telah meminta mereka untuk menggunakan perangkat teknologi untuk tujuan pembelajaran di luar kelas.

Dari data yang tersebut terlihat bahwa dosen belum memaksimalkan peran teknologi mobile untuk menjadi jembatan pembelajaran. Dosen belum memberikan ruang atau belum melihat potensi perangkat mobile di dalam pembelajaran, (Rodriguez, Spiegel, Salviolo \& Peña, 2015). Seperti yang dinyatakan sebelumnya, $65 \%$ siswa mengatakan bahwa mereka telah mempelajari sendiri penggunaan perangkatnya oleh karenanya manajemen penggunaan perangkat tersebut tidak bisa dikontrol untuk aktifitas akademik saja (Spiegel, 2013). Mahasiswa yang merupakan pembelajar dewasa belajar sendiri dari perangkat mobile mereka sendiri melalui koneksi pribadi mereka (teman, keluarga, kontak virtual, dll.). Dalam istilah ini, hanya $8 \%$ dari siswa ini yang mengakui mendapatkan pembelajaran dari 
Pendidikan atau guru di system formal. Dapat diasumsikan bahwa jumlah yang sedikit tersebut akan mengakibatkan kelemahan dalam pergeseran menggunakan perangkat mobile sebagai media pembelajaran mereka. Siswa yang penggunaan perangkat mobilenya tidak terkontrol, cenderung menggunakan hanya untuk kesnangan (for pleasure) ketimbang tujuan akademik dan hal tersebut akan sulit digeser menajdi focus pembelajaran.

Namun dalam penelitian ini hal tersebut tidak terjadi. Pada gambar 4 nampak bahwa $85 \%$ siswa merasa nyaman dan siap apabila dosen menggunakan teknologi mobile dalam aktifitas belajar dalam dan di luar kelas karena meskipun mereka tidak belajar secara formal mereka merasa tetap mendapatkan input positif terhadap diri mereka dari informasi di Internet.

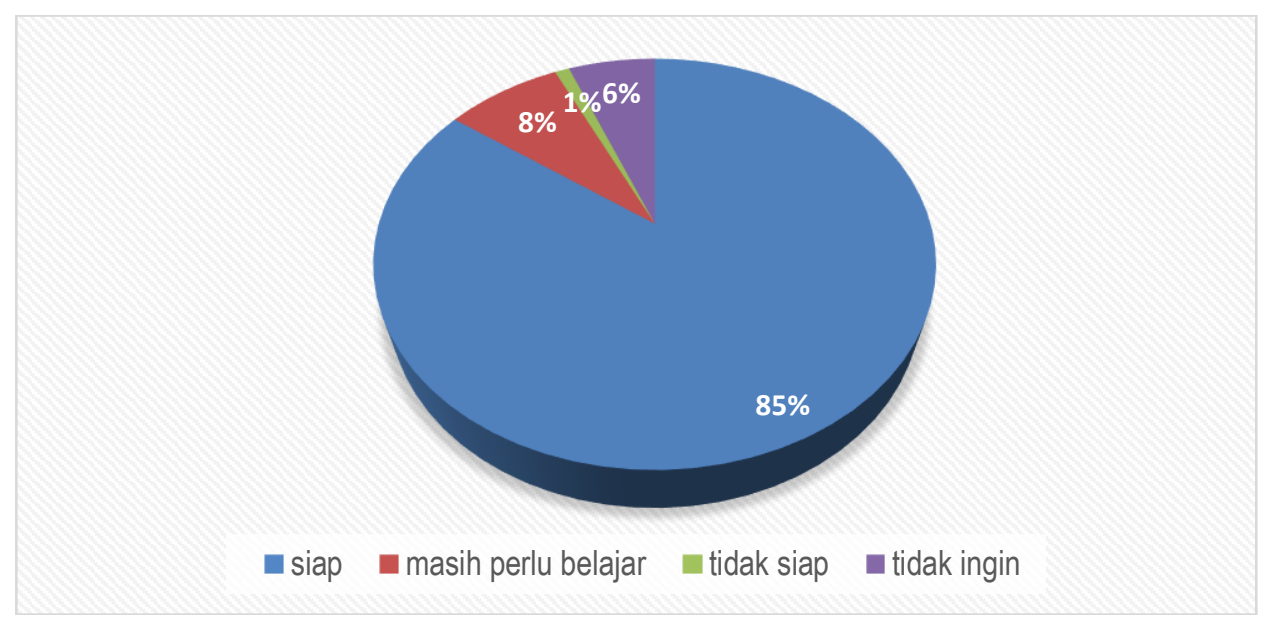

Gambar 4. Presentase Kesiapan Menggunakan Mobile Learning

Sebagian besar dosen juga memiliki perasaan yang sama tentang keterampilan siswa mereka. Ketika mereka ditanya tentang pengetahuan atau kebiasaan penggunaan teknologi mobile, mereka yakini bahwa mahasiswa telah belajar menggunakan teknologi mobile dengan mandiri sehingga tidak perlu diajarkan di kelas formal. Bahkan mereka berpendapat mahasiswa memiliki kompetensi lebih dan lebih siap dibandingkan para dosen jika suatu saat pembelajaran diarahkan menjadi m-learning. Kesiapan tersebut tergambar dari kebiasan para dosen menggunakan teknologi mobile yang hanya berputar untuk tujuan mengelola daftar pustaka, untuk mengeksplorasi, berbagi, dan menganalisis informasi, untuk membuat presentasi PowerPoint, mencari informasi di Internet, dan menggunakan e-mail dan jejaring social. Tidak ada sama sekali dosen yang memiliki intensi memanfaatkan m-learning untuk pembelajaran

Sebagaimana hasil penelitian Egaña (2013) mengatakan bahwa siswa memiliki kesulitan untuk menemukan informasi akademik yang mereka butuhkan, karena dosen atau pengajar tidak memiliki kemampuan yang lebih dari mereka ketika mencari informasi. Baik dosen dan mahasiswa mengaku kesulitan mencari informasi dalam bahasa asing dan mengumpulkan informasi dalam cara yang tidak terstuktur, otodidak dan sesuai kebutuhan. Data yang diaksespun tanpa memperhitungkan sumber darimana data dan informasi tersebut berasal. 


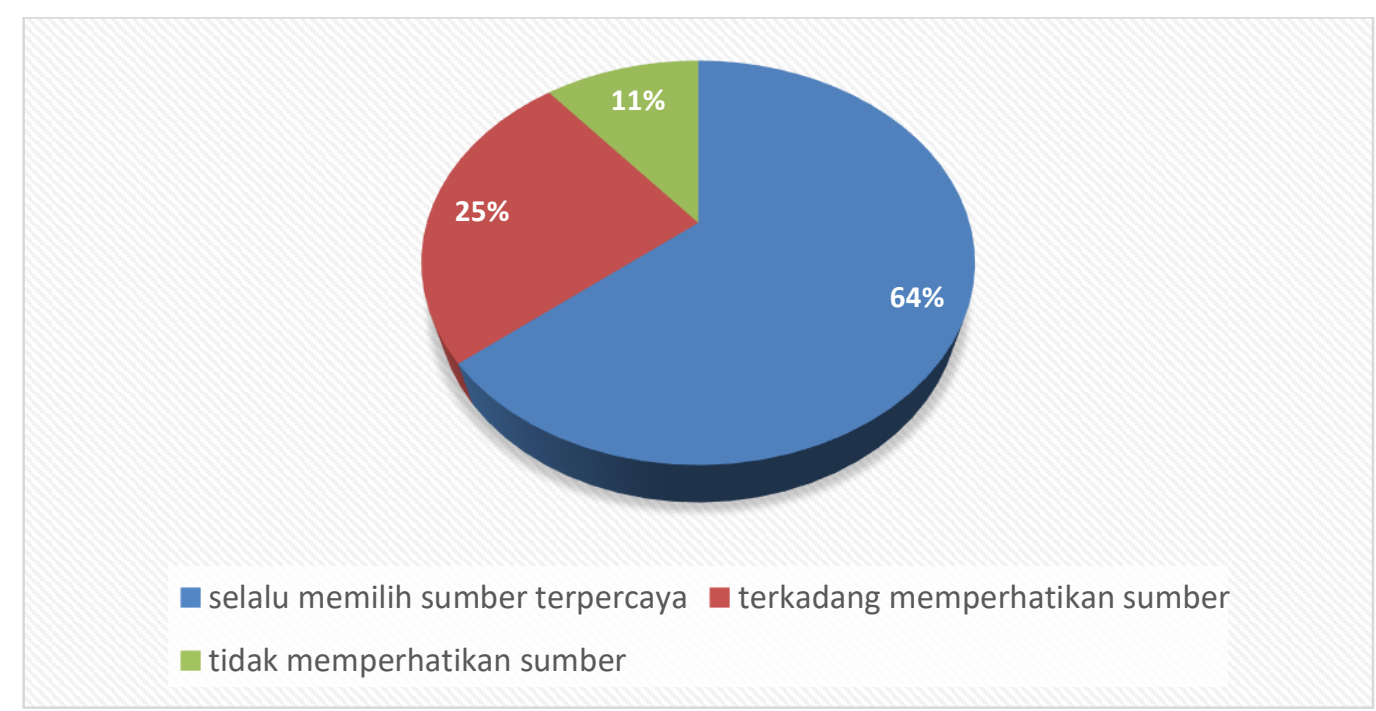

\section{Gambar 5. Presentase Pilihan Sumber Data dari Internet}

Senada dengan penelitian Egaña (2013) yang menemukan bahwa pencarian dan bahasa yang disukai oleh siswa cenderung menjadi rujukan. Dia menyatakan bahwa siswa banyak menggunakan Google untuk pencarian informasi mereka, tetapi dia tidak melihat lebih lanjut tentang cara-cara di mana informasi diberikan; mereka lebih suka opsi yang diberikan oleh mesin pencari ini. Dengan kata lain, dia tidak menanyakan apakah, bagaimana cara dan di mana informasi yang relevan bia ditemukan.

Muncul dari wawancara bahwa, sebagai bagian dari tugas akademik mahasiswa saat ini, semakin banyak siswa mencari dan menemukan jawaban di YouTube. Aktifitas lain yang terjadi didalam kelas menurut para dosen ialah banyak siswa yang merekam pelajaran yang disampaikan di kampus atas inisiatif mereka sendiri, untuk dapat mendengarkannya nanti Pergeseran dari google ke Youtube juga merupakan hal yang harus disoroti oleh dosen dalam memberikan tugas dan pembelajaran berbasis mobile. Contoh-contoh ini menunjukkan bahwa mereka berharap dosen mereka menyediakan materi jenis ini (audio visual) karena akses dukungan audiovisual portabel di perangkat mobile mereka yang menguntungkan untuk dilakukan aktifitas pengulangan.

Menurut wawancara yang dilakukan dan beberapa komentar yang dimasukkan dalam survei, cara tersebut dikategorikan sebagai cara mandiri memilih untuk mengakses pengetahuan atau yang disebut self-regulated (Rodriguez, 2014). Ini adalah contoh lain dari kesenjangan antara praktik sosial yang benar-benar dilakukan siswa dan apa yang telah dilakukan oleh dosen atau pengajar mereka. Preferensi untuk penggunaan perangkat mobile dan materi yang mendukung seperti video dan kuis online ini tidak disadari oleh sebagian besar dosen. Mereka percaya bahwa penggunaan computer yang dimiliki mahasiswa sudah mencakup keterampilan yang diperlukan untuk pencarian informasi (Spiegel, 2013), tetapi mereka tidak mencatat preferensi siswa untuk akses terhadap pengarahan dan sumber belajar lain. Akibatnya, sebagian besar sumber informasi yang diterbitkan atau direkomendasikan oleh dosen masih berbentuk teks, di atas kertas atau media yang dapat dicetak.

Pembelajaran mobile yang diyakini akan menghapus keterbatasan jarak dan waktu belum sama sekali disentuh oleh sebagian dosen dan pengajar. Menurut Valero (2012), kata "jarak" dalam konteks mlearning, menyiratkan bahwa " konten atau akses ke konten dapat dilakukan dari tempat, dan dari waktu yang tidak terikat". Namun demikian, masalah ini memang cukup rumit, asumsi bahwa pembelajaran mobile memang harus dipertimbankan aspek pengaturan mandiri, manajemen waktu atau implementasi 
yang efektif dari bentuk kegiatan-kegiatan belajar yang relevan dengan konteks kehidupan sehari-hari siswa.

Namun terlepas dari keterbatasan dan keuntungan yang ditawarkan oleh m-learning, pembelajaran tatap muka yang dosen berada di ruang kelas, adanya dosen yang mengatur tugas, memiliki kelompok untuk berbagi masalah yang sama, memang tetap harus dipertimbangkan. Kekhawatiran akan terkikisnya peran guru mengacu pada kurangnya peran guru yang melibatkan tugas berbasis teknologi mobile sejauh ini memang belum diterima. Pembelajaran mobile sejauh ini belum bisa menggantikan tatap muka, kontribusi atau keunggulan diferensial dari teknologi ini untuk proses belajar mengajar masih belum diakui (Spiegel, 2010)

Resistensi terhadap perubahan peran dosen muncul, juga karena takut kewalahan akibat akumulasi tugas yang diperlukan untuk mengadaptasi bahan-bahan dan memasukkan metodologi baru yang mengintegrasikan teknologi mobile secara aktif di dalam kelas. Dalam semua kasus, terbatasnya penggunaan teknologi yang tersedia terdeteksi mungkin terkait dengan kebutuhan pelatihan akademisi yang tidak terpenuhi. Maka kedengarannya tidak aneh bahwa, misalnya, Hanif \& Asrowi (2018) mengatakan bahwa guru yang juga merupakan mahasiswa pascasarjana saja tidak siap dengan tugas yang diberikan oleh akademisi yang melibatkan teknologi mobile; atau Pedró (2012) berargumen "jelas bahwa tidak semua guru ingin memasukkan teknologi ke dalam pengajaran mereka".

Singkatnya, tidak cukup untuk memiliki teknologi mobile untuk mencapai pembelajaran ketika melakukan m-learning. Dibutuhkan pelatihan bagi dosen dan juga mahasiswa untuk menghadapi tantangan baru ini. Namun potensi penggunaan teknologi mobile meskipun belum ditetapkan dengan kuat dalam jadwal universitas, praktik pengajaran m-learning ini sangat penting, tidak hanya untuk menambah peluang yang lebih baik untuk kinerja akademik siswa di perguruan tinggi, tetapi juga untuk praktik mereka sebagai profesional masa depan.

\section{KESIMPULAN}

Seperti yang diungkapkan di atas, siswa menggunakan teknologi mobile mereka untuk belajar, meskipun tidak ada tugas guru mereka. Sementara fakta ini dapat dilihat sebagai konsekuensi dari praktik sosial yang mereka lakukan di luar kelas. Meskipun demikan itu tidak dapat dianggap sebagai praktik pembelajaran yang terarah melainkan lebih kepada dengan penggunaan perangkat. Di sisi lain, baik dosen dan mahasiswa percaya bahwa mereka sangat mengambil keuntungan dari adanya perangkat mobile terutama dalam menunjang belajar untuk kegiatan akademik mereka (Spiegel, Rodriguez, Salviolo, Peña \& Ferrarasi, 2013). Oleh sebab itu, penting untuk merancang pelatihan dosen dan teknik pengimplementasian dukungan pedagogis bagi dosen untuk mengenali dan memanfaatkan cara-cara belajar yang baru termasuk menggunakan teknologi mobile.

Dosen harus diperkuat dalam mengembangkan teknologi mobile sebagai alat yang efektif untuk pembelajaran kolaboratif, fleksibel, spontan, informal, dan berbasis masalah (Valero, 2012). Saat mencari informasi, siswa lebih suka cara dan bahan yang mudah, tetapi sumber daya ini tidak diakomodasi sebagai pilihan ketika akademisi mempersiapkan dan menawarkan materi. Oleh karena itu, bahasa audiovisual seperti google dan youtube merupakan peluang untuk mempromosikan penggunaan Teknologi mobile di universitas.

\section{DARTAR PUSTAKA}

Ausubel, D. (2002). Acquisition and retention of knowledge: A cognitive perspective. Barcelona: Paidós. 
Cavus, N. (2011). Investigating Mobile Devices and LMS Integration in higher education: Student Perspectives. Procedia Computer Sciences, 3, 1469-1476.

Chachil, K. Engkamat, A. Sarkawi A. \&. Shuib, A. R. A. (2015). Interactive multimedia-based mobile application for learning Iban language (I-MMAPS for learning Iban language). Procedia - Social and Behavioral Sciences, 167, 267-273.

Egaña, T. et al. (2013). How do university students search for academic information online? What students and their teachers say. EDUTEC. Revista Electrónica de Tecnología Educativa, 43.

Flick, U. (1998). An Introduction to Qualitative Research. London: Sage Publications.

Jick, T. (1979). Mixing Qualitative and Quantitative Methods: Triangulation in action. Administrative Science Quarterly, 24(4), 602-61

Hanif, M \& Asrowi. (2018). Mobile Learning Perception of Graduate Student Teachers: A Case Study in Magister Program of Educational Technology of University of Sebelas Maret. International Journal of Multicultural and Multireligious Understanding, 5(1), 84-91

Ozdamli, F., \& Cavus, N. (2011). Basic Elements and Characteristics of Mobile Learning. Procedia Social and Behavioral Sciences, 28 , 937-942.

Pedró, F. (2012). Is Technology transforming higher education? Evidence and implications of educational policy. http://forovalparais02012.files.wordpress.com/2012/04/francesc-pedrc3b3-enespac3b10l.pdf (last visited: 07-16)

Rodríguez, G., Spiegel, A., Salviolo, M. \& Peña, A. (2015). Math, English and Netbooks at the University. Learning Across Contexts? Procedia - Social and Behavioral Sciences 76, 714-721

Segaran, K., Ali, A. Z., \& Hoe, T. W. (2014). Usability and User Satisfaction of 3D Talking-head Mobile Assisted Language Learning (MALL) App for Non-Native Speakers. Procedia Social and Behavioral Sciences, 131, 4-10.

Spiegel, A., Rodriguez, G., Salviolo, M., Peña, A. \& Ferrarasi, S. (2013). Procedia - Social and Behavioral Sciences, 106, 1435 - 1441

Spiegel, A., \& Rodríguez, G. (2016). Students at university have mobile technologies. Do they do mlearning? Procedia - Social and Behavioral Sciences, 217, 846 - 850

Valero, C., Roura Redondo, M. \& Sanchez Palacín, A. (2012). Current trends in the use of mobile devices in education. La Educ@ción digital magazine, 147. Available at: http://educoas.org/portal/la_educacion_digital/147/pdf/ART_UNNED_EN.pdf (last visited 07/15) 